\title{
ResearchArticle
}

\section{Effect of inorganic and bio-fertilizers on growth and yield of strawberry [Fragaria $x$ ananassa L. Duch.] cv. CHANDLER in Central Uttar Pradesh}

\author{
SHASHANK VERMA, SANJAY KUMAR, SUTANU MAJI, KAMAL RAM MEENA AND RAKESH \\ KUMAR MEENA
}

\section{SUMMARY}

A field experiment was conducted during 2014-15 to study the performance of different levels of inorganic fertilizers with combination of bio-fertilizers at Babasaheb Bhimrao Ambedkar University, Lucknow. It comprised application of different level of inorganic and bio-fertilizers in Randomized Block Design with thirteen treatments i.e. $\mathrm{T}_{1}$ - Control (No inorganic and no bio-fertilizer), $\mathrm{T}_{2}-\left(100 \mathrm{~kg} \mathrm{~N} \mathrm{ha}^{-1}+\right.$ Azotobacter $), \mathrm{T}_{3}-\left(100 \mathrm{~kg} \mathrm{~N} \mathrm{ha}^{-1}+\mathrm{PSB}\right), \mathrm{T}_{4}-\left(75 \mathrm{~kg} \mathrm{~N} \mathrm{ha}^{-1}+\right.$ Azotobacter $), \mathrm{T}_{5}-(75$ $\left.\mathrm{kg} \mathrm{N} \mathrm{ha}^{-1}+\mathrm{PSB}\right), \mathrm{T}_{6}-\left(60 \mathrm{~kg} \mathrm{Pha}^{-1}+\right.$ Azotobacter $), \mathrm{T}_{7}-\left(60 \mathrm{~kg} \mathrm{Pha}^{-1}+\mathrm{PSB}\right), \mathrm{T}_{8}-\left(45 \mathrm{~kg} \mathrm{Pha}^{-1}+\right.$ Azotobacter $), \mathrm{T}_{9}-\left(45 \mathrm{~kg} \mathrm{P} \mathrm{ha}^{-}\right.$ $\left.{ }^{1}+\mathrm{PSB}\right), \mathrm{T}_{10}-\left(60 \mathrm{~kg} \mathrm{~K} \mathrm{ha}^{-1}+\right.$ Azotobacter $), \mathrm{T}_{11}-\left(60 \mathrm{~kg} \mathrm{~K} \mathrm{ha}^{-1}+\mathrm{PSB}\right), \mathrm{T}_{12}-\left(45 \mathrm{~kg} \mathrm{~K} \mathrm{ha}^{-1}+\right.$ Azotobacter $)$ and $\mathrm{T}_{13}-(45 \mathrm{~kg} \mathrm{~K}$ $\left.\mathrm{ha}^{-1}+\mathrm{PSB}\right)$. It was observed that overall minimum plant height was obtained $(14.18 \mathrm{~cm})$ at 90 days after transplanting in $\mathrm{T}_{1}$ - Control and maximum plant height $(18.67 \mathrm{~cm})$ in $\mathrm{T}_{2}-\left(100 \mathrm{~kg} \mathrm{~N} \mathrm{ha}^{-1}+\right.$ Azotobacter $)$. The maximum number of leaves was

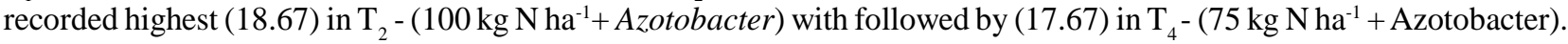
The minimum spreading of plant in North- South direction $(15.63 \mathrm{~cm})$ was recorded in case of control. The highest yield per plant observed in $\mathrm{T}_{2}(173.42 \mathrm{~g})$. Among the thirteen treatments $\mathrm{T}_{2}-\left(100 \mathrm{Kg} \mathrm{N} \mathrm{ha}^{-1}+\right.$ Azotobacter $)$ showed best performance in terms of maximum fruit yield of strawberry.

Key Words : Bio-fertilizers, Inorganic fertilizer, Growth, Yield

How to cite this article : Verma, Shashank, Kumar, Sanjay, Maji, Sutanu, Meena, Kamal Ram and Meena, Rakesh Kumar (2017). Effect of inorganic and bio-fertilizers on growth and yield of strawberry [Fragaria x ananassa L. Duch.] cv. CHANDLER in Central Uttar Pradesh. Internat. J. Plant Sci., 12 (2): 184-190, DOI: 10.15740/HAS/IJPS/12.2/184-190.

Article chronicle : Received : 14.04.2017; Revised : 15.05.2017; Accepted : 03.06.2017

\section{MEMBERS OF THE RESEARCH FORUM}

Author to be contacted :

SHASHANK VERMA, Department of Applied Plant Science (Horticulture), Babasaheb Bhimrao Ambedkar University, LUCKNOW (U.P.) INDIA

Email : shashank3978@gmail.com

Address of the Co-authors:

SANJAY KUMAR, SUTANU MAJI, KAMAL RAM MEENA AND REKESH KUMAR MEENA, Department of Applied Plant Science (Horticulture), Babasaheb Bhimrao Ambedkar University, LUCKNOW (U.P.) INDIA 